\title{
Mendeteksi Earnings Management Perusahaan Melalui Aktivitas RIIL
}

\author{
Viriany, Liana Susanto, Henny Wirianata, dan Yanti \\ Fakultas Ekonomi dan Bisnis, Universitas Tarumanagara \\ Email:viriany@fe.untar.ac.id
}

\begin{abstract}
This research was to obtained empirical evidence about the influence of leverage, profitability, institutional ownership, independent comissioner, audit committee to the Real Earnings Management of the manufacturing companies listed at Indonesian Stock Exchange from 2015-2017.This research uses 64 companies that were selected using purposive sampling method. In this study, the hypotheses tested using the multiple regression model.The results showed that only profitability has significant influence.
\end{abstract}

Keywords: Real Earnings Management, Leverage, Profitability, Institutional Ownership, Independent Commissioner, Audit Committee.

\begin{abstract}
Abstrak: Tujuan dari penelitian ini adalah untuk memperoleh bukti empiris mengenai pengaruh leverage, profitabilitas, kepemilikan institusional, dewan komisaris independen, dan ukuran komite audit terhadap Real Earnings Management dari perusahaan manufaktur yang terdaftar di Bursa Efek Indonesia dari tahun 2015-2017. Penelitian ini menggunakan 64 perusahaan yang diseleksi dengan metode purposive sampling. Hipotesis diuji dengan menggunakan model resgresi berganda. Hasil pengujian menunjukkan bahwa hanya profitabilitas yang berpengaruh signifikan.
\end{abstract}

Kata kunci: Real Earnings Management, Leverage, Profitabilitas, Kepemilikan Institusional, Dewan Komisaris Independen, Ukuran Komite Audit.

\section{PENDAHULUAN}

Laporan keuangan adalah hasil akhir dari proses akuntansi yang digunakan oleh pihak-pihak yang berkepentingan untuk menilai kinerja dari suatu perusahaan. Salah satu hal penting yang dapat digunakan untuk mengukur kinerja perusahaan adalah laba. Menurut (Scott, 2015), para pemakai laporan keuangan seperti pemegang saham, kreditur, dan pihak-pihak lainnya menggunakan informasi laba perusahaan untuk mengestimasi laba di masa depan, mengestimasi risiko investasi, dan membantu mereka dalam memutuskan pemberian pinjaman.

Karena sangat pentingnya informasi mengenai laba ini maka hal ini sering menjadi target untuk melakukan rekayasa oleh pihak manajemen perusahaan.Tindakan rekayasa ini dilakukan untuk memaksimalkan kepuasannya dan dapat dilakukan dengan memilih kebijakan akuntansi tertentu yang meningkatkan atau menurunkan laba. Tindakan ini dikenal dengan manajemen laba. Manajemen laba merupakan suatu topik yang masih sering diperdebatkan sehingga membuatnya menarik untuk diteliti. (Scott, 2015) 
mendefinisikan manajemen laba sebagai suatu tindakan yang dilakukan oleh manajemen dalam proses penyusunan laporan keuangan dengan menurunkan atau menaikan laba untuk mencapai kepentingannya.

Menurut (Talbi et al., 2015), ada dua metode manipulasi laba yaitu melalui aktivitas manajemen laba riil dan akrual. Metode manipulasi melalui cara akrual telah banyak diteliti, sedangkan manipulasi melalui aktivitas riil masih sedikit diteliti. Menurut (Kusumawati dkk., 2015), manajemen laba telah bergeser ke arah manajemen laba riil, karena metode akrual dianggap menjadi fokus pemeriksaan auditor dan terlalu berisiko apabila laporan keuangan menunjukkan nilai defisit maka kinerja manajer dianggap buruk.

Hal ini sejalan dengan pendapat (Roychowdhury, 2006), yang menyatakan meskipun Real Earnings Management (REM) mungkin dapat mengurangi nilai perusahaan, tetapi manajer cenderung untuk melakukan manajemen laba melalui aktivitas riil karena kecil kemungkinannya untuk menarik perhatian auditor atau regulator.

(Roychowdhury, 2006) dalam penelitiannya telah menemukan bahwa perusahaan-perusahaan yang diteliti melakukan manipulasi aktivitas riil seperti: mengelola penjualan, pengurangan beban-beban diskresioner, mengelola kelebihan produksi dan pengurangan beban riset dan pengembangan, untuk mencegah pelaporan rugi dalam laporan keuangan.

(Talbi et al., 2015), telah menguji tingkat terjadinya manajemen laba dalam dua periode yang berbeda, yaitu sebelum dan sesudah diberlakukannya Sarbanes-Oxley Act (SOX), yaitu hukum federal Amerika Serikat yang ditetapkan pada 30 Juli 2002 sebagai tanggapan terhadap sejumlah skandal akuntansi perusahaan besar (Enron, Tyco International, Worldcom, dan sebagainya). Cohen menemukan bahwa tingkat manajemen laba yang dilakukan dengan metode akrual, menurun setelah SOX. Tetapi, manajemen laba dengan metode riil meningkat pada periode yang sama. Hasil ini menunjukkan bahwa SOX telah memotivasi manajer untuk beralih menggunakan metode riil dalam melakukan manipilasi laba. Hal ini sejalan dengan temuan (Talbi et al., 2015).

Profitabilitas menggambarkan kinerja perusahaan dalam menghasilkan laba dengan menggunakan aktiva yang dimilikinya. Profitabilitas juga melambangkan keberhasilan perusahaan. Perusahaan yang memiliki profitabilitas rendah akan mempengaruhi manajer untuk melakukan tindakan manajemen laba, karena jika profitabilitas rendah menunjukkan bahwa besarnya laba yang diharapkan tidak tercapai dan manajer kehilangan kesempatan mendapatkan bonus yang dijanjikan perusahaan jika target laba tercapai. Jadi, semakin rendah profitabilitas perusahaan semakin mempengaruhi manajer melakukan tindakan manajemen laba.

Leverage menunjukan sumber dana operasi yang digunakan perusahaan. Hutang merupakan sumber dana eksternal yang menjadi alternatif perusahaan dijadikan sebagai sumber dana perusahaan. Perusahaan yang memiliki leverage yang tinggi cenderung lebih berisiko. Oleh karena itu, perusahaan dengan nilai leverage yang tinggi dapat mendorong terjadinya tindakan manajemen laba karena mengindikasikan perusahaan tidak mampu memenuhi kewajibannya tepat waktu. (Zamri et al., 2013) dalam penelitiannya menemukan bahwa leverage dapat membatasi aktivitas REM sehingga hal ini dapat meningkatkan kualitas dari laba akuntansi. 
Menurut (Talbi et al., 2015), berbagai mekanisme pengawasan dapat membatasi opportunictic behavior dari para manajer untuk melakukan manipulasi laba. Bentuk pengawasan terbaik yang secara umum digunakan adalah dengan menerapkan tata kelola perusahaan yang baik (Good Corporate Governance atau GCG). Penerapan GCG diharapkan dapat meningkatkan transparansi dan akuntabilitas manajer perusahaan $G C G$ adalah struktur dan mekanisme yang mengatur pengelolaan perusahaan sehingga menghasilkan nilai ekonomi jangka panjang yang berkesinambungan bagi para pemegang saham maupun pemangku kepentingan (Istianingsih, 2016). Unsur-unsur GCG dalam penelitian ini meliputi kepemilikan institusional yaitu kepemilikan non-individu dalam perusahaan, adanya komite audit, dan keberadaan komisaris independen dalam dewan komisaris perusahaan.

Menurut (Kusumawati dkk., 2015) jumlah kepemilikan institusional yang cukup signifikan dapat meminimalkan tindakan manajemen laba karena dianggap dapat mengawasi tindakan pihak manajemen sehingga dapat mengurangi motivasi mereka dalam melakukan tindakan manajemen laba. Pemegang saham institusional dalam perusahaan dapat meliputi instansi pemerintah, instansi keuangan, instansi berbadan hukum, instansi yang berasal dari luar negeri, dana perwalian atau bentuk lainnya (Pratiwi dkk., 2016).

(Kusumawati dkk., 2015), menemukan bahwa keberadaan dewan komisaris independen dapat mengurangi praktik manajemen laba, karena dewan komisaris independen dapat melakukan monitoring atas laporan keuangan sebagai bentuk aktivitas pengawasan terhadap pihak manajemen.

Menurut (Kusumawati dkk., 2015) komite audit memiliki fungsi membantu melaksanakan tugas serta fungsi dewan komisaris secara efektif, karena komite audit melaksanakan tugas dan fungsinya secara independen sehingga dapat mengurangi praktik manajemen laba.

\section{KAJIAN TEORI}

Agency Theory. Dalam teori keagenan, manajer berperan sebagai agent, sedangkan pemilik perusahaan adalah principal. Asumsi mendasar dalam teori keagenan adalah setiap individu termotivasi untuk memaksimumkan kesejahterakan dirinya sehingga terjadi konflik kepentingan antara agent yaitu manajer dan pemilik yang adalah principal. Seorang manajer bertanggungjawab untuk mewujudkan kesejahteraan bagi pemilik perusahaan yang diukur dari profitabilitas yang selalu meningkat, namun di sisi lain manajer juga memiliki kepentingan untuk memaksimumkan kesejahteraannya sendiri (Jensen dan Meckling, 1976).

Masalah dalam teori keagenan terjadi karena adanya asimetri informasi (Asymmetry Information) antara manajer dan pemilik perusahaan. Asimetri informasi tersebut timbul karena ketidakseimbangan jumlah informasi yang diketahui manajer dan pemilik perusahaan. Sebagai pihak internal perusahaan, manajer (agent) akan memiliki lebih banyak informasi tentang kondisi perusahaan jika dibandingkan dengan pemilik perusahaan (principal).

(Wiyadi dkk., 2016) menjelaskan terdapat dua jenis asimetri informasi, yaitu jenis adverse selection dan jenis moral hazard. Adverse selection merupakan kondisi dimana principal tidak yakin dalam menggunakan informasi yang disajikan oleh agent karena informasi yang diberikan belum tentu mencerminkan kinerja yang sebenarnya. Apabila 
principal tidak secara langsung melihat aktivitas agent dalam mengelola perusahaan, maka akan timbul Moral hazard, dimana manajer berkesempatan mensejahterakan kepentingan mereka dengan melakukan manajemen laba.

(Manossoh, 2016) mengemukakan tiga sifat manusia, yaitu mementingkan diri sendiri (self interest), memiliki daya pikir terbatas mengenai persepsi masa mendatang (bounded rationality), dan menghindari risiko (risk averse). Atas dasar tiga sifat tersebut, seorang manajer dapat mengutamakan kepentingan dirinya sendiri yaitu dengan memanipulasi laba pada laporan keuangan. Sifat dasar manusia ini sulit untuk dihilangkan hanya dapat diminimalisir.

Masalah keagenan juga dapat timbul karena tidak adanya keseimbangan informasi mengenai kegiatan internal perusahaan antara manajer dan pemilik perusahaan, dan kesulitan pemilik perusahaan memonitor perilaku yang dilakukan oleh manajer.

Manajemen Laba Riil. Data akuntansi dalam laporan keuangan digunakan oleh pemakai laporan keuangan untuk mengambil keputusan. Manajemen laba dapat terjadi ketika manajer menggunakan penilaian pribadi dalam menyajikan informasi di laporan keuangan perusahaan sehingga pemakai laporan keuangan memperoleh informasi yang tidak mencerminkan kondisi perusahaan yang sebenarnya (Swai dan Mbogela, 2016). Informasi tentang laba merupakan informasi yang penting sehingga seringkali dijadikan target rekayasa oleh Manajer (Istianingsih, 2016).

Manajemen laba dapat terjadi karena adanya kecenderungan dari pihak eksternal seperti para investor, kreditur dan pihak lainnya yang menilai kinerja manajemen berdasarkan laporan keuangan yang disajikan, sehingga dengan adanya kecenderungan tersebut membuat pihak manajemen berkeinginan melakukan tindakan manajemen laba untuk memperlihatkan kondisi perusahaan dan kinerja manajemen yang baik di mata pihak eksternal.

(Scott, 2015) mengemukakan bahwa manajemen laba adalah tindakan manajemen dalam proses penyusunan laporan keuangan sehingga dapat menaikkan atau menurunkan laba sesuai kepentingannya. Manajer terdorong untuk melakukan manajemen laba karena memiliki kepentingan pribadi yaitu untuk mensejahterakan dirinya.

Manajemen laba dapat dilakukan dengan dua pendekatan, yaitu manajemen laba akrual dan manajemen laba riil. Manajemen laba akrual adalah tindakan merekayasa laba perusahaan melalui aktivitas akrual yang dilakukan melalui pemilihan aktivitas dan pencatatan akrual dalam buku perusahaan, sedangkan manajemen laba riil adalah tindakan merekayasa laba melalui aktivitas-aktivitas riil. Menurut (Kusumawati dkk., 2015) manajemen laba dengan acrrual method telah berpindah dengan menggunakan real method, auditor akan lebih mudah menemukan manajemen laba dengan acrrual method daripada real method. Apabila laporan keuangan defisit maka kinerja manajemen akan dinilai tidak baik.

(Kusumawati dkk., 2015) mengemukakan bahwa manajemen laba riil dapat dilakukan dengan melakukan berbagai kegiatan seperti dengan mengadakan diskon untuk meningkatkan penjualan, sehingga barang diproduksi secara besar-besaran untuk memperkecil biaya produksi dan mengurangi pengeluaran diskresioner untuk memperbaiki margin yang ditentukan. Dengan demikian, Manajer lebih memilih untuk melakukan manajemen laba rill daripada manajemen laba akrual karena lebih mudah dilakukan. 
Leverage. Salah satu faktor penting yang mempengaruhi praktek manajemen laba adalah leverage. Leverage menunjukan sumber dana operasi yang digunakan perusahaan. Hutang merupakan sumber dana eksternal yang menjadi alternatif perusahaan dijadikan sebagai sumber dana perusahaan. Perusahaan yang memiliki leverage yang tinggi cenderung lebih berisiko. Oleh karena itu, tindakan manajemen laba cenderung dilakukan perusahaan yang memiliki rasio leverage yang tinggi. Hal ini disebabkan karena perusahaan tersebut terancam akan tidak dapat membayar hutangnya tepat waktu.

Leverage dapat didefinisikan sebagai penggunaan aset oleh perusahaan yang untuk membayar biaya tetap perusahaan namun tetap dapat meningkatkan keuntungan potensial pemegang saham (Vakilifard dan Mortazavi, 2016). Salah satu penggunaan aset adalah untuk membayar hutang dan beban bunga. Manajemen akan melakukan manajemen laba agar besarnya laba bersih dalam laporan keuangan tetap besar seperti yang diharapkan oleh para pemegang saham. Leverage dalam penelitian ini akan diukur dengan menggunakan Debt to Assets Ratio (DAR).

Profabilitas. Profitabilitas adalah kemampuan perusahaan untuk memperoleh keuntungan. Profitabilitas dapat diukur dengan menghitung rasio keuangan, seperti Return on Assets (ROA), Return on Equity (ROE), Net Profit Margin (NPM), dan rasio lainnya. Laba bersih merupakan ukuran profitabilitas yang paling penting, sebab baik kreditur maupun investor akan memantau rasio profitabilitas suatu perusahaan sebelum mengambil keputusan (Prayudi dan Daud, 2013).

Profitabilitas merupakan alat ukur keberhasilan suatu perusahaan. Semakin tinggi profitabilitasnya maka semakin tinggi kemampuan perusahaan dalam menghasilkan laba. Sebaliknya, semakin rendah profitabilitasnya maka kemampuan perusahaan untuk menghasilkan laba semakin rendah (Brigham dan Houston, 2014).

Pemakai laporan keuangan cenderung menginginkan tingkat profitabilitas yang tinggi. Hal ini akan mendorong manajemen untuk melakukan tindakan manajemen laba. Penelitian ini mengukur profitabilitas dengan ROA untuk melihat sejauh mana aset yang dimiliki perusahaan dapat menghasilkan laba bagi perusahaan.

Good Corporate Governance. Good Corporate Governance akan mengurangi manajemen laba. Apabila perusahan melakukan Good corporate gornance maka pihak investor atau principal akan lebih yakin terhadap pengembalian return yang tercantum dalam laporan keuangan yang disajikan oleh pihak manajemen.

Dalam penelitian ini Good Corporate Governance diproksikan ke dalam tiga variabel yaitu kepemilikan institusional, dewan komisaris independen dan ukuran komite audit. Kepemilikan institusional menunjukkan seberapa banyak saham perusahaan yang dimiliki oleh instansi. Pemegang saham institusional dapat meliputi pemerintah, institusi keuangan, institusi berbadan hukum, institusi luar negeri, dana perwalian dan institusi lainnya (Pratiwi, 2016). Semakin besar kepemilikan institusional dalam perusahaan, akan menjadi salah satu bentuk pengawasan bagi tindakan yang dilakukan manajemen perusahaan. Sehingga keberadaan kepemilikan insitusional dalam perusahaan diharapkan akan mencegah terjadinya manajemen laba.

Dewan komisaris independen adalah dewan komisaris dari luar yang diangkat oleh rapat umum pemegang saham, yang tidak memiliki hubungan apapun dengan pemegang 
saham utama, dewan direksi atau dewan komisaris lainnya yang diatur dalam anggaran dasar perusahaan (Pratiwi, 2016).

(Pratiwi, 2016) menjelaskan bahwa komite audit merupakan komite yang dibentuk oleh dewan komisaris dan mempunyai tugas untuk mengawasi pengelolaan perusahaan. Keberadaan dari komite audit ini sangat penting untuk pengelolaan perusahaan. Komite audit merupakan komponen yang baru dalam sistem pengendalian perusahaan dan dianggap sebagai penghubung antara pihak investor dan dewan komisaris dengan pihak manajemen dalam menangani masalah pengendalian.

Pengaruh Leverage Terhadap Real Earnings Management. Leverage akan mendorong terjadinya praktek manajemen laba karena perusahaan mempunyai kewajiban tetap untuk membayar hutang tapi di sisi lain manajemen harus dapat menghasilkan laba yang besar bagi para pemegang saham dan investor lainnya. Oleh karena itu, semakin tinggi tingkat leverage perusahaan maka akan memperbesar peluang terjadinya praktek manajemen laba. Sebaliknya, semakin rendah tingkat leverage maka akan memperkecil praktek manajemen laba (Wiyadi dkk., 2016). (Firdaus, 2013) menemukan bahwa leverage tidak berpengaruh terhadap Real Earnings Management. Berdasarkan penjelasan tersebut maka disusun hipotesis pertama sebagai berikut:

Ha1 : Leverage berpengaruh signifikan terhadap Real Earnings Management

Pengaruh Profitabilitas Terhadap Real Earnings Management. Perusahaan yang memiliki profitabilitas rendah akan mempengaruhi manajer untuk melakukan tindakan manajemen laba, karena jika profitabilitas rendah menunjukkan bahwa target laba yang ditetapkan tidak tercapai dan manajer tidak memperoleh bonus yang dijanjikan perusahaan jika target laba tercapai. Jadi, semakin rendah profitabilitas perusahaan, akan semakin mempengaruhi manajer melakukan tindakan manajemen laba (Wiyadi dkk., 2016). Atas penjelasan tersebut maka hipotesis kedua disusun sebagai berikut:

Ha2 : Profitabilitas berpengaruh signifikan terhadap Real Earnings Management

Pengaruh Kepemilikan Institusional Terhadap Real Earnings Management. Kepemilikan institusional yang tinggi dapat mengurangi tindakan manajemen laba. Dalam (Kusumawati dkk., 2015) terbukti bahwa kepemilikan institusional memiliki pengaruh signifikan negatif terhadap manajemen laba. Dari penjelasan di atas dapat disusun hipotesis ketiga sebagai berikut:

Ha3 : Kepemilikan Institusional berpengaruh signifikan terhadap Real Earnings Management

Pengaruh Dewan Komisaris Independen Terhadap Real Earnings Management. Dewan komisaris independen diyakini mampu mengurangi praktek manajemen laba di sebuah perusahaan. Semakin banyak jumlah anggota dewan komisaris independen maka semakin besar pengawasan yang bisa dilakukan terhadap kegiatan operasional yang dijalankan oleh manajemen (Kusumawati dkk., 2015; Nabila dan Daljono, 2013). Atas penjelasan tersebut maka hipotesis keempat disusun sebagai berikut: 
Ha4 : Dewan Komisaris berpengaruh signifikan terhadap Real Earnings Management

Pengaruh Ukuran Komite Audit Terhadap Real Earnings Management. Seperti halnya dewan komisari independen, komite audit juga dibentuk untuk mengawasi jalannya perusahaan terutama dalam penyajian laporan keuangan. Apabila komite audit dapat melaksanakan tugasnya dengan baik maka praktek manajemen laba dapat dikurangi (Kusumawati dkk., 2015). (Augustia, 2013) menemukan bahwa ukuran komite audit tidak berpengaruh signifikan terhadap earnings management. Maka, dapat disusun hipotesis kelima sebagai berikut:

Ha5 : Ukuran Komite Audit berpengaruh signifikan terhadap Real Earnings Management

Model dalam penelitian ini dapat digambarkan sebagai berikut:

Gambar 1. Model Penelitian

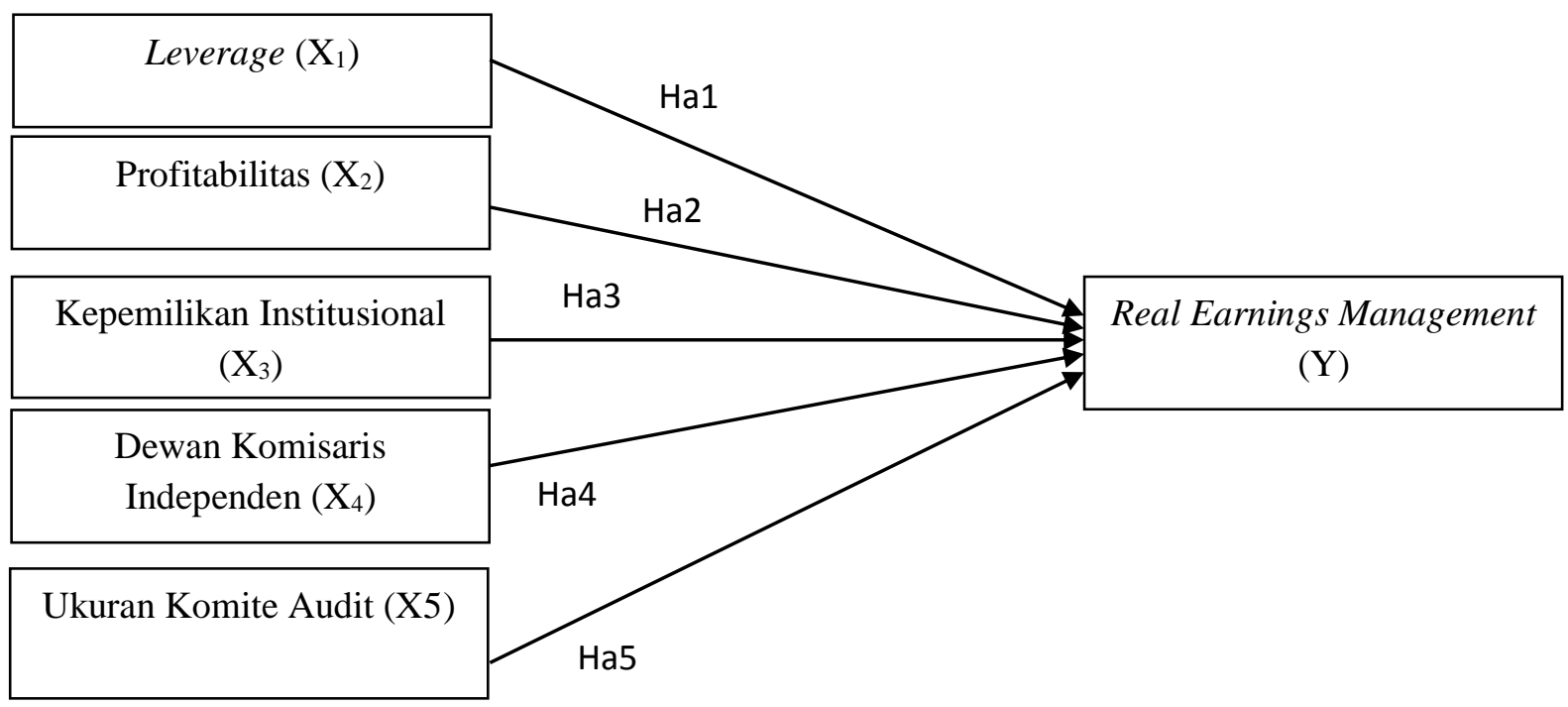

\section{METODOLOGI}

Populasi dan Sampel. Pemilihan populasi sebagai objek penelitian dalam penelitian ini adalah seluruh perusahaan manufaktur yang terdaftar di Bursa Efek Indonesia (BEI) tahun 2015 sampai dengan 2017. Teknik pemilihan sample yang digunakan adalah purposive sampling dengan menggunakan kriteria tertentu untuk memilih sampel penelitian. Kriteria-kriteria adalah sebagai berikut: 1. Perusahaan manufaktur yang secara konsisten terdaftar di Bursa Efek Indonesia (BEI) selama tahun 2014-2017, 2. Perusahaan manufaktur yang menyajikan laporan keuangan menggunakan mata uang Rupiah selama tahun 2014-2017, 3.Perusahaan manufaktur yang tidak mengalami kerugian selama tahun 2014-2017 dan 4. Perusahaan manufaktur yang menyajikan laporan keuangan per 31 Desember selama tahun 2014-2017. 
Operasionalisasi Variabel Penelitian. Variabel dependen yang digunakan dalam penelitian ini adalah Real Earnings Management. Real Earnings Management diukur dengan menggunakan 3 proksi yang dikembangkan oleh (Roychowdhury, 2006), yaitu Abnormal Cash Flow Operations (Abn CFO); Abnormal Production Costs (Abn PROD); dan Abnormal Discretionary Expenses (Abn DISC).

Abnormal CFO (Arus Kas Operasi Abnormal). Arus kas operasi abnormal diperoleh dari selisih nilai arus kas operasi aktual yang diskala dengan total aset satu tahun sebelum pengujian dikurangi dengan arus kas kegiatan operasi normal yang dihitung dengan menggunakan koefisien estimasi dari model persamaan regresi sebagai berikut:

$\mathrm{CFO}_{\mathrm{t}} / \mathrm{AT}_{\mathrm{t}-1}=\alpha_{0}+\alpha_{1}\left(1 / \mathrm{AT}_{\mathrm{t}-1}\right)+\alpha_{2}\left(\mathrm{~S}_{\mathrm{t}} / \mathrm{AT}_{\mathrm{t}-1}\right)+\alpha_{3}\left(\Delta \mathrm{S}_{\mathrm{t}} / \mathrm{AT}_{\mathrm{t}-1}\right)+\varepsilon_{\mathrm{t}}$

Keterangan:

$\mathrm{CFO}_{\mathrm{t}} \quad=$ Arus kas Operasi pada tahun $\mathrm{t}$

$\mathrm{AT}_{\mathrm{t}-1} \quad=$ Total aset perusahaan pada tahun $\mathrm{t}-1$

$S_{\mathrm{t}} \quad=$ Penjualan perusahaan pada tahun $\mathrm{t}$

$\Delta S_{\mathrm{t}} \quad=$ Penjualan perusahaan pada tahun $\mathrm{t}$ dikurangi penjualan tahun $\mathrm{t}-1$

$\alpha \quad=$ Konstanta

$\varepsilon \quad=$ Error term

\begin{abstract}
Abnormal PROD (Biaya Produksi Abnormal). Biaya produksi abnormal dihitung dari selisih nilai biaya produksi aktual yang di skala dengan total aset satu tahun sebelum pengujian dikurangi dengan biaya produksi normal yang dihitung dengan menggunakan koefisien estimasi dari model persamaan regresi sebagai berikut:
\end{abstract}

$\mathrm{PROD}_{\mathrm{t}} / \mathrm{AT}_{\mathrm{t}-1}=\alpha_{0}+\alpha_{1}\left(1 / \mathrm{AT}_{\mathrm{t}-1}\right)+\alpha_{2}\left(\mathrm{~S}_{\mathrm{t}} / \mathrm{AT}_{\mathrm{t}-1}\right)+\alpha_{3}\left(\Delta \mathrm{S}_{\mathrm{t}} / \mathrm{AT}_{\mathrm{t}-1}\right)+\alpha_{4}\left(\Delta \mathrm{S}_{\mathrm{t}-1} / \mathrm{AT}_{\mathrm{t}-1}\right)+\varepsilon_{\mathrm{t}} \ldots(2)$

Keterangan:

PROD $_{\mathrm{t}}=$ Biaya produksi perusahaan pada tahun $\mathrm{t}$

$\mathrm{AT}_{\mathrm{t}-1}=$ Total aset perusahaan pada tahun $\mathrm{t}-1$

$S_{\mathrm{t}} \quad=$ Penjualan perusahaan pada tahun $\mathrm{t}$

$\Delta S_{\mathrm{t}} \quad=$ Penjualan perusahaan pada tahun $\mathrm{t}$ dikurangi penjualan tahun $\mathrm{t}-1$

$\Delta S_{\mathrm{t}-1} \quad=$ Perubahan penjualan pada tahun $\mathrm{t}-1$

$\alpha \quad=$ Konstanta

$\varepsilon \quad=$ Error term

\begin{abstract}
Abnormal DISC (Biaya Diskresioner Abnormal). Biaya diskresioner abnormal diperoleh dari selisih nilai biaya diskresioner aktual yang diskala dengan total aset satu tahun sebelum pengujian dikurangi dengan biaya diskresioner normal yang dihitung dengan menggunakan koefisien estimasi dari model persamaan regresi sebagai berikut:
\end{abstract}


$D I S C_{\mathrm{t}} / \mathrm{AT}_{\mathrm{t}-1}=\alpha_{0}+\alpha_{1}\left(1 / \mathrm{AT}_{\mathrm{t}-1}\right)+\alpha_{2}\left(\Delta \mathrm{S}_{\mathrm{t}-1} / \mathrm{AT}_{\mathrm{t}-1}\right)+\varepsilon_{\mathrm{t}}$

Keterangan:

$$
\begin{array}{ll}
D I S C_{\mathrm{t}} & =\text { Biaya diskresioner perusahaan pada tahun } \mathrm{t} \\
\mathrm{AT}_{\mathrm{t}-1} & =\text { Total aset perusahaan pada tahun } \mathrm{t} \\
\Delta S_{\mathrm{t}-1} & =\text { Perubahan penjualan pada tahun } \mathrm{t}-1 \\
\alpha & =\text { Konstanta } \\
\varepsilon & =\text { Error term }
\end{array}
$$

Setelah diperoleh hasil dari masing-masing proksi maka nilai dari masing-masing proksi tersebut dijumlahkan dalam rangka menentukan efek secara menyeluruh dari Real Earnings Management. Agar arah proksi menjadi sama maka Abn_CFO dan Abn_DISC dikalikan dengan min 1 sebelum dijumlahkan. Jadi proksi untuk menghitung REM menggunakan persamaan sebagai berikut:

$R E M=-1\left(A b n \_C F O\right)+A b n \_P R O D+-1$

(Abn_DISC).

Keterangan:

REM = Real Earnings Management

Abn_CFO = Abnormal Cash Flow Operations

Abn_PROD = Abnormal Production Costs

Abn_DISC = Abnormal Discretionary Expenses

\section{Variabel Independen}

Leverage. Dalam penelitian ini, variabel independen pertama yaitu leverage diproksikan dengan rasio Debt to Total Assets (DAR) yang menurut Wiyadi, dkk (2016) dapat dirumuskan sebagai berikut:

$$
\text { DAR }=\text { Total Liabilities/ Total Assets }
$$

Profitabilitas. Variabel independen kedua dalam penelitian ini yaitu profitabilitas diukur dengan menggunakan proksi Return on Assets (ROA) yang menurut Wiyadi, dkk (2016) dapat dirumuskan sebagai berikut:

$$
\text { ROA = Net Income/ Total Assets }
$$

Kepemilikan Institusional. Variabel independen ketiga adalah kepemilikan institusional (KI) yang menurut Swai dan Mbogela (2016) dapat dirumuskan sebagai berikut: 
$\mathrm{KI}=$ proporsi total saham perusahaan yang dimiliki oleh investor institusi

Dewan Komisaris Independen. Dalam penelitian ini, variabel independen keempat adalah dewan komisaris independen (DKI) yang menurut (Kusumawati dkk., 2015) dapat dirumuskan sebagai berikut:

DKI $=$ Persentase jumlah dewan komisaris independen terhadap jumlah total komisaris yang ada di perusahaan

Ukuran Komite Audit. Variabel independen kelima dalam penelitian ini adalah ukuran komite audit (UKA) yang menurut (Susanto, 2016) dapat dirumuskan sebagai berikut:

\section{$\mathrm{UKA}=$ Jumlah Komite Audit}

Teknik Pengumpulan Data. Teknik pengumpulan data pada penelitian ini menggunakan teknik observasi dengan memperoleh data dari laporan keuangan. Data yang digunakan merupakan data sekunder berupa data laporan keuangan perusahaan. Semua data yang digunakan diakses melalui situs BEI yaitu: www.idx.co.id. Laporan keuangan yang digunakan dari perusahaan manufaktur yang terdaftar di Bursa Efek Indonesia (BEI) pada periode 2015-2017.

Teknik Pengolahan Data. Data dari laporan keuangan perusahaan dikumpulkan dengan menggunakan software MicrosoftExcel 2007 dan diolah menggunakan program E-views. Analisis regresi berganda untuk data panel digunakan dalam penelitian ini. Data panel merupakan gabungan antara data time series dan data cross section.

Statistik Deskriptif. Pengujian ini dimaksudkan untuk memperjelas keadaan dan karakteristik variabel-variabel yang digunakan dalam penelitian, antara lain: nilai mean, standar deviasi, varian maksimum, minimum, sum, range, kurtosis dan skewness (Ghozali, 2016).

Analisis Regresi Data Panel. Analisis regresi liner berganda dengan data panel dilakukan untuk mendapatkan bukti empiris sejauh mana pengaruh leverage, profitabilitas, kepemilikan institusional, dewan komisaris independen, dan ukuran komite audit terhadap Real Earnings Management. Menurut (Ajija, 2011), terdapat 3 model yang dapat digunakan untuk menggunakan data panel yaitu Pooled Least square (PLS), Fixed Effect, dan Random Effect.

Selanjutnya, untuk menemukan model yang terbaik antara Common Effect, Fixed Effect dan Random Effect, maka digunakan 2 jenis pengujian, yaitu:

Uji Chow atau Likehood ratio. Uji Chow bertujuan untuk menentukan manakah model yang terbaik antara Common Effect atau Fixed Effect. Jika nilai probabilitas > 0,05 maka model yang terbaik adalah model Common Effect. Jika nilai probabilitas < 0,05 maka model yang terbaik adalah Fixed Effect. 
Uji Hausman. Uji ini digunakan untuk menentukan diantara Random Effect Model atau Fixed Effect Model.

Jika nilai probabilitas cross section random $>0,05$ maka model yang terbaik adalah random effect. Sebaliknya bila nilai probabilitas cross section random $<0,05$ maka model terbaik adalah Fixed Effect.

Uji Hipotesis. Dalam penelitian ini digunakan analisis regresi linier berganda dengan persamaan regresi sebagai berikut:

$R E M_{i t}=\alpha+\beta_{1} \mathrm{LEV}_{i t}+\beta_{2} \mathrm{PROF}_{i t}+\beta_{3} K I_{i t}+\beta_{4} \mathrm{DKI}_{i t}+\beta_{5} \mathrm{UKA}_{i t}+\mathrm{e}$

Keterangan:

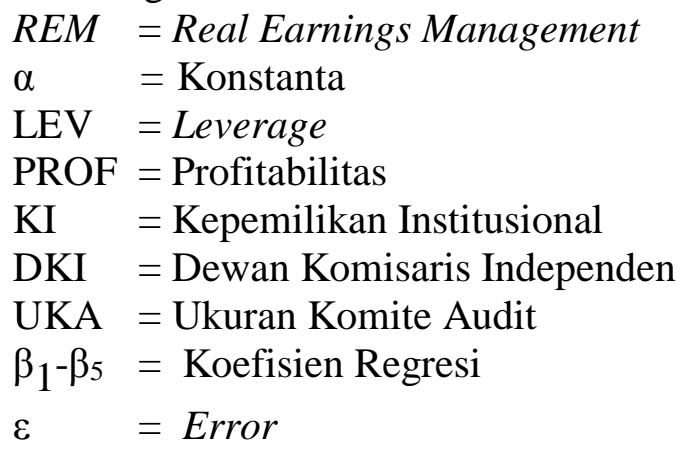

Uji F. Uji F bertujuan untuk menguji the goodness of fit dari sebuah model penelitian. Tingkat signifikansi yang digunakan adalah 0,05 (Priyatno, 2012). Jika nilai prob ( $F$ Statistic) $<0,05$ maka $\mathrm{H}_{0}$ ditolak, sedangkan jika sebaliknya maka $\mathrm{H}_{0}$ diterima.

Uji t. Uji t untuk menguji apakah secara parsial variabel independen berpengaruh secara signifikan terhadap variabel dependen. Pengujian menggunakan tingkat signifikansi 0,05. Jika nilai prob $<0,05$ maka Ho ditolak, dan jika sebaliknya maka $\mathrm{H}_{0}$ diterima (Priyatno,2012).

Uji Koefisien Determinasi Ganda (Adjusted $\boldsymbol{R}$ square). Uji ini dipakai untuk menunjukkan koefisien determinasi antara dua atau lebih variabel independen terhadap variabel dependen. Semakin nilai adjusted $R^{2}$ mendekati 1 maka dikatakan kemampuan variabel independen untuk memprediksi variasi variabel dependen sangat rinci karena hampir semua informasi yang dibutuhkan diberikan (Priyatno, 2012).

\section{DISKUSI}

Hasil Statistik Deskriptif. Berdasarkan kriteria-kriteria yang telah ditentukan maka sampel yang digunakan adalah 64 perusahan. Data yang digunakan untuk analisis deskriptif yaitu sebanyak 192 data pengamatan. Statistik deskriptif menggambarkan karakter dari variabel yang digunakan dalam penelitian ini. Karakteristik yang diuji dideskriptifkan meliputi nilai minimum, nilai maksimum, rata-rata dan standar deviasi dari variabel independen. Dalam tabel 1 berikut ini disajikan hasil pengujian statistik deskriptif untuk masing-masing variabel. 
Tabel 1. Hasil Statistik Deskriptif

\begin{tabular}{lrccccc}
\hline \hline & Y & LEV & ROA & \multicolumn{1}{c}{ INST_OWN KOM_IND KOM_AUDIT } \\
\hline Mean & 0.010708 & 0.403956 & 0.084965 & 0.674055 & 0.390411 & 3.089474 \\
Median & 0.552715 & 0.384340 & 0.065545 & 0.672700 & 0.333330 & 3.000000 \\
Maximum & 4.966210 & 0.933230 & 0.526700 & 0.997300 & 0.666670 & 5.000000 \\
Minimum & -8.058250 & 0.083060 & 0.000180 & 0.011370 & 0.200000 & 3.000000 \\
Std. Dev. & 2.426858 & 0.181386 & 0.083029 & 0.238285 & 0.090394 & 0.321035 \\
Skewness & -1.004804 & 0.287182 & 2.202654 & -0.779876 & 0.456328 & 3.789575 \\
Kurtosis & 4.422599 & 2.428436 & 9.477514 & 3.342641 & 3.027484 & 17.82337 \\
& & & & & & \\
Jarque-Bera & 47.99333 & 5.197928 & 485.8056 & 20.18933 & 6.600109 & 2194.309 \\
Probability & 0.000000 & 0.074351 & 0.000000 & 0.000041 & 0.036881 & 0.000000 \\
& & & & & & \\
Sum & 2.034490 & 76.75167 & 16.14339 & 128.0704 & 74.17814 & 587.0000 \\
Sum Sq. Dev. & 1113.142 & 6.218273 & 1.302942 & 10.73135 & 1.544342 & 19.47895 \\
& & & & & & \\
\hline
\end{tabular}

Sumber: (Data diolah, 2019)

Hasil Uji Chow atau Likehood Ratio. Pengujian ini dilakukan untuk memilih model yang lebih baik atau tepat untuk mengestimasi data panel antara Pooled Least Square Model (Common Effect Model) dengan Fixed Effect Model. Dari hasil uji Chow diperoleh nilai probabilitas sebesar 0.0000 atau lebih kecil dari 0.05. Hal ini berarti H0 ditolak atau model yang terbaik digunakan adalah Fixed Effect Model.

Hasil Uji Hausman. Uji Hausman bertujuan untuk pemilihan model yang tepat untuk mengestimasi data panel antara Fixed Effect Model atau Random Effect. Hasil uji Hausman menunjukkan nilai probabilitas cross section random sebesar 0.0006 atau lebih kecil dari 0.05 sehingga $\mathrm{HO}$ ditolak. Hal ini menunjukkan bahwa model yang terbaik digunakan adalah Fixed Effect Model.

Model Regresi Berganda. Hasil pengujian regresi berganda tersaji pada tabel 2 di bawah ini:

Tabel 2. Hasil Analisis Regresi Berganda

\begin{tabular}{ccccc}
\hline \hline Variable & Coefficient & Std. Error & t-Statistic & Prob. \\
\hline \hline C & -46.61086 & 11.48483 & -4.058472 & 0.0001 \\
LEV & 0.274603 & 1.338576 & 0.205146 & 0.8378 \\
ROA & -4.462723 & 2.156034 & -2.069876 & 0.0406 \\
INST_OWN & -0.219201 & 0.272042 & -0.805761 & 0.4220 \\
KOM_IND & 0.228832 & 0.489871 & 0.467127 & 0.6413 \\
KOM_AUDIT & -0.763880 & 0.677936 & -1.126773 & 0.2621 \\
\hline \hline
\end{tabular}

Sumber: (Data diolah, 2019) 
Berdasarkan tabel 2 maka model untuk persamaan regresi berganda yang digunakan dalam penelitian ini dapat dirumuskan sebagai berikut:

$Y=-46,61086+0,274603 X 1-4,462723 X 2-0,219201 X 3+0.228832 X 4-0,763880$

$\mathrm{X} 5+\mathrm{e}$

Keterangan:

$\mathrm{Y} \quad=$ Real Earnings Management

$\mathrm{X} 1=$ Leverage

$\mathrm{X} 2 \quad=$ Profitabilitas $(\mathrm{ROA})$

$\mathrm{X} 3=$ Kepemilikan Institusional

X4 = Dewan Komisaris Independen

X5 = Ukuran Komite Audit

Hasil Uji t. Berdasarkan tabel 2 hasil uji t untuk setiap variabel independen dapat diuraikan sebagai berikut: (1) Nilai probabilitas untuk Leverage adalah 0.8378 , lebih besar dari nilai tingkat signifikansi $(\alpha)$ 0,05, maka dapat disimpulkan bahwa Hal ditolak artinya leverage tidak berpengaruh signifikan terhadap Real Earnings Management. (2) Nilai probabilitas untuk profitabilitas adalah 0.0406 , lebih kecil dari nilai tingkat signifikansi $(\alpha)$ 0,05, maka dapat disimpulkan bahwa Ha1 diterima artinya profitabilitas berpengaruh signifikan terhadap Real Earnings Management. (3) Nilai probabilitas untuk kepemilikan institusional adalah 0.4220 , lebih besar dari nilai tingkat signifikansi $(\alpha) 0,05$, maka dapat disimpulkan bahwa Ha1 ditolak artinya kepemilikan institusional tidak berpengaruh signifikan terhadap Real Earnings Management. (4) Nilai probabilitas untuk dewan komisaris independen adalah 0.6413 , lebih besar dari nilai tingkat signifikansi $(\alpha) 0,05$, maka dapat disimpulkan bahwa Hal ditolak artinya dewan komisaris independen tidak berpengaruh signifikan terhadap Real Earnings Management. (5) Nilai probabilitas untuk ukuran komite audit adalah 0.2621 , lebih besar dari nilai tingkat signifikansi $(\alpha) 0,05$, maka dapat disimpulkan bahwa Ha1 ditolak artinya ukuran komite audit tidak berpengaruh signifikan terhadap Real Earnings Management. Hasil ini sejalan dengan (Agustia, 2013).

Hasil Uji F. Uji F bertujuan untuk menguji the goodness of fit dari sebuah model penelitian. Hasil uji F dapat dilihat pada tabel 3 di bawah ini.

Tabel 3. Hasil Uji F

\begin{tabular}{llll}
\hline \hline F-statistic & 18.25369 & Prob(F-statistic $)$ & 0.000000 \\
\hline
\end{tabular}

Sumber: (Data diolah, 2019)

Berdasarkan tabel 3 dapat dilihat bahwa nilai prob (F Statistic) adalah 0.0000 atau dibawah 0.05. Dari hasil ini maka dapat disimpulkan bahwa model regresi yang digunakan dalam penelitian ini memenuhi the goodness of fit.

Hasil Uji Koefisien Determinasi Ganda (Adjusted $\boldsymbol{R}^{2}$ ). Hasil uji koefisien determinasi ganda dapat dilihat pada tabel 4 di bawah ini: 
Tabel 4. Hasil Uji Koefisien Determinasi Ganda

\begin{tabular}{lll}
\hline R-squared & $0.913012 \quad$ Adjusted R-squared & 0.862994 \\
\hline
\end{tabular}

Sumber: (Data diolah, 2019)

Berdasarkan tabel hasil uji koefiesien determinasi diperoleh angka adjusted $R$ Square sebesar 0.862994, artinya persentase sumbangan atas pengaruh variabel leverage, profitabilitas, kepemilikan institusional, dewan komisaris independen dan ukuran komite audit terhadap real earning management adalah sebesar $86,29 \%$, sedangkan sisanya dipengaruhi oleh variabel lainnya yang tidak digunakan dalam penelitian ini.

\section{KESIMPULAN}

Penelitian ini bertujuan untuk menganalisis pengaruh Leverage, Profitabilitas, Kepemilikan Institusional, Dewan Komisaris Independen, dan Ukuran Komite Audit terhadap Real Earnings Management perusahaan manufaktur yang terdaftar pada BEI tahun 2015-2017. Penelitian ini menggunakan data panel dan pengujian yang dilakukan adalah pengujian statistik deskriptif, Uji Chow, dan Uji Hausman menggunakan Eviews.

Hasil pengujian hipotesis menunjukan bahwa hanya variabel profitabilitas yang diproksikan dengan $R O A$ yang mempunyai pengaruh signifikan terhadap Real Earnings Management, sedangkan variabel leverage yang diproksikan dengan DER, variabel Good Corporate Governance yang diukur dari kepemilikan institusional, dewan komisaris independen, dan ukuran komite audit juga tidak berpengaruh signifikan terhadap Real Earning Management.

Berdasarkan hasil penelitian yang ada, dapat dilakukan penelitian selanjutnya dengan menambah variabel independen seperti Firm Size. Selain itu, penelitian selanjutnya dapat dilakukan dengan menambah periode penelitian dan menambah sampel perusahaan di bidang industri yang lain sehingga hasil penelitian dapat menghasilkan kesimpulan yang lebih menyeluruh untuk mengetahui faktor-faktor yang mempengaruhi praktek Real Earnings Management.

\section{DAFTAR PUSTAKA}

Agustia, Dian. (2013). Pengaruh Faktor Good Corporate Governance, Free Cash-Flow dan Leverage Terhadap Manajemen Laba. Jurnal Akuntansi dan Keuangan, 15(1), 27 42.

Ajija, S.R. (2011). Cara Cerdas Menguasai EViews. Jakarta: Salemba Empat.

Brigham, E. F. and Houston, J. F. (2014). Fundamentals of Financial Management 14th Edition. Mason: Thomson South-Western.

Ghozali, I. (2016). Aplikasi Analisis Multivariate Dengan Program IBM SPSS 23, Edisi 8. Semarang: Badan Penerbit Universitas Diponegoro.

Istianingsih. (2016). Deteksi Manajemen Laba Melalui Discretionary Revenue dan Aktifitas Riil: Implikasi Penerapan Good Corporate Governance. Jurnal Riset Akuntansi dan Keuangan, 4(3), 1125-1142.

Jensen, M. C. and Meckling, W. H. (1976). Theory of The Firm: Manajerial Behavior, 
Agency Cost and Ownership Structure. Journal of Financial Economics, 3, 305-360.

Kusumawati, E., Trisnawati, R., dan Mardalis, A. (2015). Pengaruh Corporate Governance Terhadap Manajemen Laba Riil. The 2nd University Research Coloquium, 339-350.

Manossoh, H. (2016). Good Corporate Governance Untuk Meningkatkan Kualitas Laporan Keuangan. Jakarta: PT. Norlive Kharisma Indonesia.

Nabila, Afifa dan Daljono. (2013). Pengaruh Proporsi Dewan Komisaris Independen, Komite Audit, dan Reputasi Auditor Terhadap Manajemen Laba. Diponegoro Journal of Accounting, 2(1), 1-10. Niri, Naser Nandiri. (2014).

Pratiwi, F. L. (2016). Analisis Mekanisme Good Corporate Governance Terhadap Manajemen Laba Pada Perusahaan Manufaktur Yang Terdaftar di BEI. Journal Riset Mahasiswa Akuntansi (JRMx), 4 (1), 1-15.

Prayudi, Dimas dan Daud, Rochmawati. (2013). Pengaruh Profitabilitas, Risiko Keuangan,Nilai Perusahaan dan Struktur Kepemilikan Terhadap Praktik Perataan Laba Pada Perusahaan Manufaktur tahun 2008-2011, e-prints. Unsri. Palembang. 9 (2). pp. 118-137. ISSN 1858-2702

Priyatno, D. (2012). Cara Kilat Belajar Analisis Data dengan SPSS 20, Edisi 1. Yogyakarta: ANDI.

Roychowdhury, S. (2006). Earnings Management Through Real Activities Manipulation. Journal of Accounting and Economics. 42 (3). 335-370.

Scott, W. R. (2015). Financial Accounting Theory, $7^{\text {th }}$ Edition. Canada: Pearson.

Susanto, Y. K. (2016) Corporate Governance and Real Earnings Management.International Journal of Business, Economics, and Law.9 (1).17-23.

Swai, J. P. and Mbogela, C. S. (2016). Accrual-Based Versus Real Earnings Management; The Effect Of Ownership Structure: Evidence From East Africa. ACRN Oxford Journal of Finance and Risk Perspectives, 5(2), 121-139.

Vakilifard, H. and Mortazavi, M. S. (2016). The Impact of Financial Leverage on AccrualBased and Real Earnings Management. International Journal of Academic Research in Accounting, Finance and Management Sciences, 6(2), 53-60.

Talbi, D., Omri, M. A., Guesmi, K., and Ftiti, Z. (2015). The Role of Board Characteristic in Mitigating Management Opportunism: The Case Of Real Earnings Management. The Journal of Applied Business Research, 31(2), 661-674.

Wiyadi, Trisnawati, R., Puspitasari, N., dan Sasongko, N. (2016). Pengaruh Asimetri Informasi, Leverage dan Profitabilitas Terhadap Manajemen Laba Riil pada Perusahaan Manufaktur di Indonesia. The $3^{\text {rd }}$ University Research Coloquium, 93-103.

Zamri, N., Abdul Rahman, R., Mohd Isa, N.S. (2013). The impact of leverage on real earnings management, Procedia Economic and Finance, (7), 86-95. 26. 